\title{
A Study on Ubiquitous English Learning for Policing
}

\author{
WEI Li \\ Liaoning Police Academy
}

\begin{abstract}
On the basis of previous practice on Virtual Policing in English and related literature on Ubiquitous Learning, a scenario-based ubiquitous learning environment of English for Policing is created in which students integrate role-plays into multimedia classroom instructions, take part in simulated policing training after class, learn English and fulfill virtual policing service through QQ software on Internet-connected computers and WeChat software on smartphones. The program is implemented on free messaging tools and Virtual Policing in English Network developed with Dreamweaver, aiming at providing the students a seamless, autonomous and vocation-related learning environment anytime, anywhere with available devices. Results show that most of the participants enjoy the learning process with high interests though limitations do exist and to be overcome in the future.
\end{abstract}

Keywords: Online training, QQ, Ubiquitous learning, Virtual Policing in English Network, WeChat

\section{Introduction}

Teaching students to be literate is a high educational priority and a great challenge in China as well as in other countries throughout the world. The teaching and learning environment has changed dramatically with the development of the innovative technology. Computers are still viewed as supportive tools but not integral parts in language learning in most of the universities nowadays, and the teaching materials are basically the same as the textbooks presented with multimedia facilities in the teacher-centered classrooms, teachers direct the learning process and students assume a receptive role in their education.

Ubiquitous Learning (also referred to as u-learning) is any kind of learning in which learners can have access to information almost anywhere, anytime in different contexts. A Ubiquitous Learning Environment is an environment in which learners have access to knowledge through technology and work cooperatively to learn almost anywhere at any time, regardless of their geographical location. Essentially, a Ubiquitous Learning Environment provides a student with a pervasive setting in which learning can take place, even if the student or learner may not realize that he or she is learning [1].

The purpose of this study is to construct a ubiquitous English learning environment for the students in Liaoning Police Academy based on the prior research on web-based Virtual Policing in English training in the past eight years, developing a guide for English teachers in other universities to train their students in teaching English as a Foreign Language under the guidance of Cloud Based Learning. The methodology can be applied in English for General Purpose learning as well as other spheres of English for Specific Purpose, such as English for Business, for travelling.

\section{Related Studies}

An interactive u-learning system was designed to help conceptualize and maximize advantages of ubiquitous environment learning. The design is enabled by state-of-the-art web technologies; real-time collaboration technologies for a highly interactive experience; intelligent recommender systems to help learners connect with relevant content and other learners; and mining and analytics to assess learner outcomes [2]. Joung-Souk Sung proposed the implementation of learning between student and teacher of service provider in $\mathrm{u}$ space, which is not limited to traditional e-learning system. Student-focused testing services include: excellent test paper creation/deletion/registration; 7 phase framework; database development; and PDA page design [3]. Abdulrahman Alsheail described the U-learning methodology by expounding on the design, adjustment, development of EFL learning in a ubiquitous learning environment [1], providing little information about how the students made use of the new environment in detail. This study probes into a new and specific approach to apply Ubiquitous Learning in English as a Foreign Language education.

\section{Methodology}

The Ubiquitous English Learning for Policing program aims at creating a ubiquitous learning environment for students in the police academy by interacting with policing service recipients in a virtual workplace online and on campus, enabling the learning of English for Policing to take place anytime, anywhere 
with available devices. It shifts the teacher from a traditional instructor to a facilitator, a participant and a supervisor, leaving the center of the stage to the students.

Most of the participants of the program are undergraduates of Liaoning Police Academy majoring in Criminal Trace Inspect, Cyber Crime Investigation, Criminal Investigation, online learning participants also include English teachers, teachers of policing courses, police experts, police officers, foreign teachers from America and Australia, students of other four universities.

\subsection{Scenario-based Virtual Policing in English Network}

To construct a virtual and proactive environment in which students can interact with other participants including peers, teachers, experts, policemen or native English speakers free of stress to prepare them for real policing service, the Network was designed for online learning, classroom instructions and face to face simulated training. The components of the Network are shown in Table 1:

Table 1 Components of Virtual Policing in English Network

\begin{tabular}{lll}
\hline Components & \multicolumn{1}{c}{ Functions } & \multicolumn{1}{c}{ Features } \\
\hline Register or Login & $\begin{array}{l}\text { Teachers can supervise and evaluate } \\
\text { every student in his or her real ID }\end{array}$ & Student number is required \\
\hline English learning & $\begin{array}{l}\text { To learn English for General Purpose } \\
\text { and English for Policing }\end{array}$ & $\begin{array}{l}\text { The textbook and courseware of } \\
\text { English for policing are developed by } \\
\text { the research team to suit the learners' } \\
\text { specific needs }\end{array}$ \\
\hline $\begin{array}{l}\text { Scenario-based } \\
\text { training }\end{array}$ & $\begin{array}{l}\text { To apply the learnt English language } \\
\text { points in solving real work problems }\end{array}$ & $\begin{array}{l}\text { Scenarios are designed to practice } \\
\text { language and professional skills }\end{array}$ \\
\hline $\begin{array}{l}\text { Forums \& } \\
\text { reflections }\end{array}$ & To be student-centered & $\begin{array}{l}\text { ensure Student Voice to be taken into } \\
\text { account in the program }\end{array}$ \\
\hline $\begin{array}{l}\text { Tertiary indexed } \\
\text { assessment }\end{array}$ & $\begin{array}{l}\text { To be fare and open in the evaluation } \\
\text { of the students' learning result and } \\
\text { process }\end{array}$ & $\begin{array}{l}\text { Process-oriented assessment to } \\
\text { encourage students of different English } \\
\text { levels }\end{array}$ \\
\hline
\end{tabular}

A scenario is designed in accordance with the principle of being vocation and curriculum related, multi-disciplinary to train the students the ability to solve practical problems or fulfill vocational duties in English; being holistic and completed to cover all the aspects of future work and provide systematic professional situation training for the students to select in view of one's personal preference; being authentic and complicated to arouse learning interests by revising real criminal cases, making use of multimedia technologies like 3D, Virtual Real.

The scenario is also designed in accordance with a template containing the title, pre-requisite skills, time allocated, time and place, characters involved (with icons or photos for the students to change their previous ones before starting the virtual training), plots, objectives (to compel the students to master the specific language competences), the quantitative and processed-oriented assessment standards, and lastly, some references for individual choice.

\subsection{Activities in the Ubiquitous Learning Environment}

More experienced, confident and motivated English learners are expected to be fostered in the process. Students create or integrate new knowledge in scenario-based training with existing knowledge attained in curriculum learning, the experience together with student voice and reflections make them more confident and motivated to review the learnt knowledge or to learn new knowledge, a virtuous cycle goes on and on in the ubiquitous learning.

\subsubsection{Multimedia classroom role-play}

The Network is first utilized in the classroom instruction, the teacher-centered instruction can help the students to build up solid preliminary language knowledge, in the meantime, role-play among the teacher and the students are carried out based on the designed scenarios. In an English for General Purpose classroom, the scenario is designed in view of the styles of the text and the related vocabulary on policing, like a forum or debate is designed for an argumentation; a short play for a narration; an expo for an exposition. A case in point is the scenario entitled Persuading an Internet Addict for the story of A Virtual Life, see Table 2 for details of the scenario. In an English for policing classroom, the scenario is designed in view of the working field like recruits training, police administration, criminal investigation, traffic control, detection of drunk driving, interrogating the suspect or questioning the witness. 
Table 2 Scenario of Persuading an Internet Addict [4]

\begin{tabular}{|c|c|}
\hline Title & $\begin{array}{c}\text { Persuading an Internet Addict } \\
\text { (advantages and disadvantages of surfing on the Internet) } \\
\text { (5minutes) }\end{array}$ \\
\hline Setting & $\begin{array}{l}\text { Place: Sky Internet Café, Zhongshan Squarest } \\
\text { Time: } 2 \text { o'clock in the morning }\end{array}$ \\
\hline Characters & 1.An Internet Safety Administration Police Officer \\
\hline Plots & $\begin{array}{l}\text { The Police Officer finds the boy surfing online at } 2 \text { am, checks his ID first, and then } \\
\text { persuades him not to spend too much time online, The boy explains the reasons why he } \\
\text { stays so late at first, but he is finally persuaded and goes back home. }\end{array}$ \\
\hline Objectives & $\begin{array}{l}\text { The boy is convinced that internet addiction is harmful to his health and does no good } \\
\text { for his family and study, he is grateful to the officer and goes back home immediately. }\end{array}$ \\
\hline Assessment & $\begin{array}{l}\text { 1. English proficiency }(0.45) \\
\text { 2. key words and expressions }(0.20) \\
\text { 3. objectives achievement }(0.15) \\
\text { 4. professional skills } \quad(0.10) \\
\text { 5. self-improvement } \quad(0.10)\end{array}$ \\
\hline References & $\begin{array}{l}\text { 1. Hello, this is my certificate. Please show me your ID certificate. } \\
\text { 2. How could you concentrate on class tomorrow? } \\
\text { 3. Advantages of the internet: Faster and speedy communication; Information } \\
\text { Resources; Entertainment, play games, watch films, listen to music; Social networking, } \\
\text { forums, QQ messaging; Online services and e-commerce } \\
\text { 4. Disadvantages: Social problems, waste of time, spoil the health, waste of money, } \\
\text { unwilling to connect to people; Theft of Personal Information; Virus Threat; } \\
\text { Pornography. } \\
\text { 5. Background information: Civilian Police persuade young abandon jump from } \\
\text { internet addiction }\end{array}$ \\
\hline
\end{tabular}

\subsubsection{Simulated policing training}

One office is decorated as the police station with facilities of communication and service, it is not only the place where students can take part in simulated policing service training but also the central office of the program where participants can meet and develop the webpage for the each virtual police department.

\subsubsection{Web-mediated learning and virtual training}

Students can have autonomous learning in or after class, the place with a computer connected to the Internet can be a multimedia classroom, the dormitory or one's home, the students can login Virtual Policing in English Network to learn College English or English for Policing at their own pace, the textbook and courseware of English for Policing is English for Elite Police which consists of listening and speaking audio materials, police document writing, case study, police transcripts, police jokes and related videos [5]; they can also participate a discussion or Virtual Policing in English training, a student selects a scenario and finds one or more partners online to logins his or her QQ account in English, change his or her icon and nickname with the photos and character in the chosen scenario, interacts with the other participants acting as the service recipients such as the suspects, the victims, the witnesses or the help seekers. They can communicate through text, audio or video messaging to achieve the objectives with the assistance of the QQ software like group chat, sending files including photos, screen capture, checking message history and translator.

The author also hosts an online English learning community of QQ group named Growing-up for the students to discuss topics derived from the text, hot issues, pop songs, music or films to have a topic discussion to experience cultural diversity and enhance multicultural awareness[6].

\subsubsection{Wi-Fi based learning and training}

As Wi-Fi technology is becoming more and more popular among students who take their mobile phones almost everywhere, there is a novel examination approach that the participant need not physically appeared the examination but can write the test / present a seminar/ evaluate a test paper / submit the feedback / participate in a quiz etc remotely either login in their laptops or through their android [7]. 
As a matter of fact, most of the students take part in Growing up QQ group through their smart mobile phones rather than through computers when they type, but they can't have voice chat on QQ through their mobile phones. Spoken English, however, is one of the most crucial competencies a student should develop, voice chat is strongly encouraged to practice oral English in our program while video chat is not recommended as anonymity can reduce the inhibition that impedes language learning. That's why we turn to the latest and most popular communicative method among college students called WeChat.

WeChat is a mobile phone text and voice messaging communication service developed by Tencent in China. Clients are available for platforms such as Android and iPhone. Languages supported include English, traditional or simplified Chinese and other languages. WeChat is supported on Wi-Fi, 3G, and 4G data networks [8].

Most of the files on Virtual Policing in English Learning Network are transformed into webpage for the Wechat users to visit, especially the previous DOC format scenarios are converted into HTML format, MOD videos are converted into FLV or MP4 format. A registered smartphone user can interact with one or more smartphone users or Internet connected computer users to do the following on WeChat:

Autonomous learning: visit English learning webpage on Virtual Policing in English Learning Network, study the course by browsing the text, listening to audios and watch videos. Students can visit related websites of foreign police departments listed on the Network, watch police training videos, play vocationrelated games like hostage negotiation, or consult bilingual dictionaries.

Virtual training: We make full use of WeChat advantages in multimedia communication flexibility and convenience with text messaging and voice messaging in our virtual training. A user sets a new icon and a nickname for him/herself in accordance with a specific scenario, invites one or more contacts to join the virtual training, changes the displayed nickname(s) of the training partner(s) on his or her phone, starts chatting through typing, voice chat or video chat, sends pictures, screenshots. Chatting with one person can be set at the top of the chatting list. Audio chat is carried out on WeChat through sending and receiving recorded audio files with an optional hold-to-talk mode and audio message replay if necessary. "Shake, Look Around" can help the students to find a nearby potential partner on campus or within the classroom.

Student voice and reflections: The user data on WeChat is protected via on-demand contact list backup and retrieval from a cloud-based service. Students may participate a survey, express their viewpoints, suggestions on the public forum, "friend circle" is utilized as the private zone for an individual student where he or she can control viewers and reviews, uploads homework, learning reflections, photos or videos.

Some of the features of WeChat are helpful to the teachers in student assessment, the text and voice massages are stored in the message history so the teacher can check and evaluate the performance of the students, and there is also a late response time display if one is lagged behind in responding later than several minutes.

\section{Results and Conclusion}

A survey was conducted among online participants and in the classroom at the end of 2012 when the program had been implemented for a semester.

The average score of English for Elite Police and the Network rated by 38 learners in the Academy is 92 with comments like "It's delicately designed and quite relevant to my future work", "I am quite interested in the new style of learning and training" and "It's terrific, I like it". As for the online participants, $60 \%$ prefer online learning to face to face learning or hybrid model; $96 \%$ prefer anonymous (virtual) training to real identity training and $60 \%$ think online learning contributes to their learning interests. The results prove a positive attitude from the students and participants of the program and learning interests are the endless power to advance any new learning methodology.

Based on the implications of Ubiquitous Learning for education [1], our study makes efforts in shifting the learning to student-centered and enjoyable from the learner's perspective, and training students in a proactive or real life setting, simulated or virtual, which play important roles in arousing their learning interests. The limitations of the study include, first of all, inadequate technological innovations in making learning environment "free of stress" and making the process more effective like the construction of scenario data base in its amount, standard and retrieval function. Secondly, the integration of the Network into classroom instruction, online training on the two different messaging tools needs more time, energy, motivations, founds and supports to make it perfect. Thirdly, study on the application of WeChat is far from enough in taking advantages of all the features, solving possible problems, and achieving optimized utilization.

A comprehensive application of traditional facilities, latest web-mediated and mobile devices improves learners' interests through interactive and anonymous training in a seamless environment. A new road leading to Ubiquitous Learning is ahead, together with other travelers, we are on the road and prepared to try our best. 


\section{Acknowledgements}

The research is financed by the Twelfth Five-year Plan for Educational Science Project of Liaoning Province (2012) No. JG12EB082J and the 2012 teaching reform research key project of Liaoning Police Academy Application of Vocational Scenarios in Web-mediated Foreign Language Training and Processoriented Assessment.

\section{References}

[1] Abdulrahman Alsheail, Teaching English as a Second /Foreign Language in a Ubiquitous Learning Environment, Master diss., California State University, Chico, 2010.

[2] Tae-sik Ki, Towards the Design of an Interactive U-Learning System, Journal of Security Engineering,9(2), 2012,189-198.

[3] Joung-Souk Sung, U-Learning Model Design Based on Ubiquitous Environment, International Journal of Advanced Science and Technology, 13, 2009, 77-88

[4] Zhongwen Liu, Construction and Application of Scenarios in College EFL Learning, International Forum of Teaching and Studies, 8(2), 2012, 32-40.

[5] Zhongwen Liu, English for Elite Police (Press of Chinese People's Public Security University, 2009).

[6] WEI Li, A Study on College EFL Learning Community Based on QQ International, International Journal of Applied Linguistics and English Literature, 3, 2012.

[7] S. Madhavi, Hye-jin Kim, Novel Examination Scenarios for U-Learning using Characteristic Diagrams, International Journal of $u$ - and e-Service, Science and Technology, 5(4), 2012, 31-40.

[8] [Online] Available: http://en.wikipedia.org/wiki/WeChat, Feb. 2, 2013. 